\title{
Evaluation the Early Effects of Compression Stockings on Patient Satisfaction in Acute Proximal Deep Vein Thrombosis
}

\author{
Akut Proksimal Derin Ven Trombozlarında Medikal Tedavi ile Kullanılan \\ Kompresyon Çoraplarının Hasta Memnuniyetine Erken Dönem Etkilerinin \\ Değerlendirilmesi
}

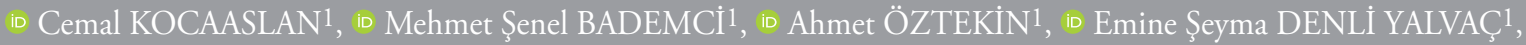
(i) Fatih BAYRAKTAR2 ${ }^{2}$, id Ebuzer AYDIN1

Iİstanbul Medeniyet Üniversitesi Göztepe Eğitim ve Araştırma Hastanesi, Kalp ve Damar Cerrahi Kliniği, İstanbul, Türkiye ${ }^{2}$ Muş Devlet Hastanesi, Kalp ve Damar Cerrahi Kliniği, Muş, Türkiye

\begin{abstract}
Objective: The effective treatment of acute deep vein thrombosis (DVT) has great importance in the prevention of major complications [pulmonary embolism, postthrombotic syndrome (PTS)]. Compression stockings (CS) can also be used to improve the outcome. The aim of this study was to evaluate the effectiveness of CS on PTS prevention in patients with proximal DVT and the effectiveness of the visual analog score (VAS) method to assess patient's satisfaction about pain.

Methods: Between January 2016 and August 2018, 92 patients with proximal acute DVT included in study . They were divided into two groups according to the use of CS. Under knee level and medium pressure computed tomography were used in addition to standard medical treatment. Both groups were followed for 6 months. Baseline, $3^{\text {rd }}$ month, $6^{\text {th }}$ month VAS scores were calculated and also baseline and $6^{\text {th }}$ month visual clinical severity score (VCSS) and Villalta score were calculated.

Results: There was no significant difference between the two groups when VAS scores were compared at baseline and $3^{\text {rd }}$ month followup. At the $6^{\text {th }}$ month follow-up, VAS values were significantly lower in favor of Group II, that used CS ( $\mathrm{p}<0.05)$. No statistically significant difference was found between the basal and $6^{\text {th }}$ month results of Villalta and VCSS scores between the groups.
\end{abstract}

\section{ÖZ}

Amaç: Alt extremite proksimal tutulumlu akut derin ven trombozu (DVT) tedavisinin etkinliği, hastalığın önemli komplikasyonlarının [pulmoner emboli, posttrombotik sendrom (PTS)] önlenebilmesinde büyük önem taşımaktadır. Planlanan (medikal ve/veya girişimsel) tedaviye ilaveten kullanılabilen kompresyon çorapları (KÇ) tedavi sonuçlarını etkileyebilmektedir. Bu çalışmada proximal DVT'li hastalarda KÇ kullanımının PTS gelişimi üzerine etkinliği ile aynı semptomatik tedavide ağrıya yönelik hasta memnuniyetinin vizuel analog skor (VAS) yöntemi ile değerlendirilmesinin etkinliği araştırıldı.

Yöntemler: Çalışmaya Ocak 2016 ile Ağustos 2018 tarihleri arasında akut DVT tanılı 92 hasta dahil edildi. Proksimal tutulumu olan 92 hasta kompresyon kullanımına göre 2 gruba ayrıldı. Dizaltı ve orta basınçlı kompresyon çorabı kullanıldı. Her iki grup standart medikal tedaviye ilaveten 6 ay süre ile takip edildi. Bazal, 3. ay, 6 . ay VAS skorları ile bazal ve 6 . ay visual clinical severity score (VCSS) ve Villalta skorları hesaplandı.

Bulgular: Hastaların bazal ve 3. ay takiplerindeki VAS değerleri karşılaştırıldığında her iki grup arasında anlamlı bir fark saptanmadı. Altıncı ay takiplerinde ise VAS değerleri KÇ kullanan Grup 2 lehine istatistiksel olarak anlamlı şekilde düşük tesbit edildi
Address for Correspondence: Cemal KOCAASLAN, İstanbul Medeniyet Üniversitesi Göztepe Eğitim ve Araştırma Hastanesi, Kalp ve Damar Cerrahi Kliniği, İstanbul, Türkiye

E-mail: cemalkocaaslan@yahoo.com ORCID ID: orcid.org/0000-0002-1348-2411
Received: 03.01.2020

Accepted: 18.02 .2020

Cite this article as: Kocaaslan C, Bademci MŞ, Öztekin A, Denli Yalvaç EŞ, Bayraktar F, Aydın E. Evaluation the Early Effects of Compression Stockings on Patient Satisfaction in Acute Proximal Deep Vein Thrombosis. Bezmialem Science 2021;9(3):259-63. 
Conclusion: CS has no effect on preventing PTS at the patients with proximal acute DVT but has an impact on reducing pain symptoms. VAS is an effective method to evaluate the effect of CS on patient satisfaction about pain.

Keywords: Acute proximal deep vein thrombosis, compression stockings, visual analog scale $(\mathrm{p}<0,05)$. Gruplar arasında Villalta ve VCSS skorlarının bazal ve 6 . ay sonuçları arasında istatistiksel olarak anlamlı bir farklılık tespit edilmedi.

Sonuç: Proksimal tutulumlu alt extremite akut DVT'si olan hastaların tedavisinde kullanılan KÇ’nin PTS gelişimi üzerine etkinliği saptanmamış olup ağrı semptomunun azaltılmasında etkinliği bulunmaktadır. KÇ kullanımının hasta memnuniyetine etkisinin değerlendirilmesinde VAS etkili bir yöntemdir.

Anahtar Sözcükler: Akut proksimal derin ven trombozu, kompresyon çorabı, vizuel analog skala

\section{Introduction}

Acute deep vein thrombosis (DVT) is seen with a frequency of $1 / 1,000$ in the general population and is an important cause of mortality and morbidity, especially in the hospitalized patients, when evaluated in terms of the complications it may cause (pulmonary embolism, post thrombotic syndrome) (1). Today, in the treatment of acute DVT with lower extremity proximal involvement (common femoral vein and/or iliac venous involvement), new catheter-based interventions (2) and accompanying medical treatments are important steps in the prevention of post thrombotic syndrome (PTS), which is the most frightening long-term complication of the disease. has been recorded. However, PTS can still develop in $30-50 \%$ of all patients (3). In addition to these treatments; compression stocking (CS) is used in acute DVT in order to relieve edema due to stasis and venous hypertension and the associated pain, and to prevent the development of PTS. When current guidelines are examined, routine use of CS is not recommended in preventing the development of PTS after acute DVT (4). Although CS contains difficulties in terms of patient compliance, it is still used in routine practice because it regresses patients' symptoms.

A visual analogue scale (VAS) can be used to numerically express the satisfaction of the patients with DVT with symptomatic acute proximal involvement who used CS in addition to medical treatment, in terms of the reduction of pain in the follow-up (5). VAS is a method that provides patient-based measurement between "no pain" and "the most severe pain" in vertical or horizontal plane of $10 \mathrm{~cm}$ length divided into equal parts. In this study, the effectiveness of CS added to the medical treatment of patients with acute proximal DVT on the development of PTS in the early period and the effectiveness of evaluating patient satisfaction with VAS method in the same patient group who were given symptomatic treatment for pain were investigated.

\section{Method}

Between January 2016 and August 2018, 151 patients who were admitted to our clinic with a diagnosis of acute DVT and were treated with CS in addition to medical treatment were retrospectively analyzed and 92 were included in the study who met the inclusion criteria. Three patients with active cancer, 10 patients who underwent percutaneous interventional procedure,
14 patients with popliteal and/or distal segment involvement, 4 patients with recurrent DVT, 4 patients who were pregnant, 8 patients below 20 years of age or over 70 years of age, and 16 patients whose follow-up records could not be accessed were excluded from the study. Medium pressure $(23-32 \mathrm{mmHg}$ ) below-knee CS was given to the patients. Thirty-seven patients who could not comply with CS in the 1st week outpatient controls were followed up with only medical treatment and were identified as Group I. Fifty-five patients who were compliant with the use of CS were named as Group II. The VAS scores of the patients were calculated before the treatment, in the $3^{\text {rd }}$ month and $6^{\text {th }}$ month of the treatment (Figure 1). The Villalta (Figure 2) score and the venous clinical severity score (VCSS) (Figure 3) of the patients in the beginning of the treatment and in the $6^{\text {th }}$ month were calculated. In medical treatment, subcutaneous enoxaparin treatment at a dose of $1 \mathrm{mg} / \mathrm{kg} / 12$ hours was started in all patients, followed by oral warfarin at a dose that would provide the effective INR (2-2.5) level, on a patient-based basis. The study was approved by the local ethics committee and all data were evaluated retrospectively before and after treatment. The patients were informed about the treatment to be applied to them, and their consent was obtained.

\section{Statistical Analysis}

Baseline, $3^{\text {rd }}$ month and $6^{\text {th }}$ month VAS scores and baseline, $6^{\text {th }}$ month Villalta and VCSS measurements were expressed as mean \pm standard deviation. Independent sample t-test was used to compare VAS, Villalta, VCSS scores between Group I and Group II. Descriptive data were presented as mean standard deviation, median (minimum, maximum) or frequency (\%). Independent samples t-test and $\chi^{2}$ test were used to compare groups according to normality test results. SPSS (IBM Corp. Released 2012. IBM SPSS Statistics for Windows, Version 21.0. Armonk, NY: IBM Corp.) package program was used for statistical analysis and $\mathrm{p}<0.05$ was considered statistically significant.

\begin{tabular}{|lllllllllll|}
0 & 1 & 2 & 3 & 4 & 5 & 6 & 7 & 8 & 9 & 10 \\
\hline No pain & \multicolumn{1}{l|l|}{} \\
\hline
\end{tabular}

Figure 1. Visual analogue scale 


\section{Results}

Ninety-two patients who were planned to use CS in the medical treatment of acute DVT were included in the study. The demographic characteristics of all patients are shown in Table 1. The basal, $3^{\text {rd }}$ month and $6^{\text {th }}$ month average VAS scores of the patients before CS treatment were 7, 7 and 5 in Group I, and 7, 6 and 5 in Group II, respectively (Table 2). When the VAS scores at baseline and $3^{\text {rd }}$ month follow-up were compared, no significant difference was observed between the two groups, while a statistically significant difference was found in favor of Group II, which used CS, in terms of VAS values at the $6^{\text {th }}$ month follow-up $(\mathrm{p}<0.05)$. Basal and $6^{\text {th }}$ month average Villalta scores of the patients before compression therapy were 8 and 6 in Group I, and 7 and 6 in Group II, respectively (Table 2). The basal and $6^{\text {th }}$ month average VCSS scores of the patients before compression therapy were; 6 and 5 in Group I, and 6 and 5 in Group II, respectively. There was no statistically significant

\begin{tabular}{|l|l|}
\hline \multicolumn{1}{|c|}{ Symptoms } & \multicolumn{1}{c|}{ Clinical findings } \\
\hline Pain & Edema \\
\hline Cramp & Skin hardness \\
\hline Feeling of heaviness & Hyperpigmentation \\
\hline Rash & Redness \\
\hline Paresthesia & Pain during calf compression \\
\hline & Venous ectasia \\
\hline $\begin{array}{l}\text { Every symptom /Clinical findings; } 0 \text { (no), 1 (light), 2 (middle), 3 } \\
\text { (severe) }\end{array}$ & \\
\hline Scoring & PTS no \\
\hline $0-4$ & Light-middle PTS \\
\hline $5-15$ & High PTS \\
\hline$>15$ or venous ulcer stenosis &
\end{tabular}

Figure 2. Villalta score difference in terms of the baseline and $6^{\text {th }}$ month Villalta and VCSS scores between the groups.

\section{Discussion}

In this study, the early results of the use of medium pressure CS in patients with symptomatic DVT with acute proximal

\begin{tabular}{|c|c|c|c|c|}
\hline $\begin{array}{c}\text { Clinical } \\
\text { descriptors }\end{array}$ & No (-) & Light (1) & Middle (2) & High (3) \\
\hline Pain & No & Rare & $\begin{array}{l}\text { Does not } \\
\text { restrict } \\
\text { daily life }\end{array}$ & $\begin{array}{l}\text { Restricting } \\
\text { daily life }\end{array}$ \\
\hline Varicose vein & No & Little & $\begin{array}{l}\text { Calf and } \\
\text { thigh } \\
\text { region }\end{array}$ & $\begin{array}{l}\text { Calf and } \\
\text { thigh region }\end{array}$ \\
\hline Venous edema & No & $\begin{array}{l}\text { Foot and } \\
\text { wrist }\end{array}$ & $\begin{array}{l}\text { Under the } \\
\text { knees }\end{array}$ & $\begin{array}{l}\text { Knee and } \\
\text { above }\end{array}$ \\
\hline $\begin{array}{l}\text { Skin } \\
\text { pigmentation }\end{array}$ & No & $\begin{array}{l}\text { Perimalleolar } \\
\text { region } \\
\text { limited }\end{array}$ & $\begin{array}{l}\text { Common } \\
\text { sub } 1 / 3 \\
\text { calf region }\end{array}$ & $\begin{array}{l}\text { Much more } \\
\text { common } \\
\text { top } 1 / 3 \text { calf } \\
\text { region }\end{array}$ \\
\hline Inflammation & No & $\begin{array}{l}\text { Perimalleolar } \\
\text { region } \\
\text { limited }\end{array}$ & $\begin{array}{l}\text { Common } \\
\text { sub } 1 / 3 \\
\text { calf region }\end{array}$ & $\begin{array}{l}\text { Much more } \\
\text { common } \\
\text { top } 1 / 3 \text { calf } \\
\text { region }\end{array}$ \\
\hline Skin hardening & No & $\begin{array}{l}\text { Perimalleolar } \\
\text { region } \\
\text { limited }\end{array}$ & $\begin{array}{l}\text { Common } \\
\text { sub } 1 / 3 \\
\text { calf region }\end{array}$ & $\begin{array}{l}\text { Much more } \\
\text { common } \\
\text { top } 1 / 3 \text { calf } \\
\text { region }\end{array}$ \\
\hline $\begin{array}{l}\text { Number of } \\
\text { active venous } \\
\text { ulcers }\end{array}$ & No & 1 & 2 & $\geq 3$ \\
\hline $\begin{array}{l}\text { Venous ulcer } \\
\text { duration }\end{array}$ & No & $<3$ month & $\begin{array}{l}3-12 \\
\text { month }\end{array}$ & $>1$ year \\
\hline $\begin{array}{l}\text { Active venous } \\
\text { ulcer diameter }\end{array}$ & No & $<2 \mathrm{~cm}$ & $2-6 \mathrm{~cm}$ & $>6 \mathrm{~cm}$ \\
\hline $\begin{array}{l}\text { Compression } \\
\text { therapy }\end{array}$ & No & Intermittent & Most days & $\begin{array}{l}\text { Throughout } \\
\text { the } \\
\text { treatment }\end{array}$ \\
\hline
\end{tabular}

Figure 3. VCSS scoring

Table 1. Demographic characteristics of the patients

\begin{tabular}{|c|c|c|c|}
\hline & Group I ( $n=37)$ & Group II ( $n=55)$ & $p$ \\
\hline Gender (female) & $22(59 \%)$ & $33(60 \%)$ & $0.958^{\mathrm{a}}$ \\
\hline Age & $46.33 \pm 11.21(18-72)$ & $48.09 \pm 10.31(18-72)$ & $0.601^{\mathrm{b}}$ \\
\hline BMI & $24.72 \pm 11.20(20-33)$ & $24.73 \pm 20-35$ & $0.992^{b}$ \\
\hline \multicolumn{4}{|l|}{ CEAP category } \\
\hline $\mathrm{C} 3$ & $16(43.2 \%)$ & $26(47.2 \%)$ & \\
\hline
\end{tabular}


involvement were examined. While CS had no effect on the development of PTS, it was found to have a reducing effect on the pain as assessed by VAS. In the follow-up of patients with DVT, many evaluation systems have been used to evaluate both the development of PTS and the regression of symptoms, and VCSS and Villalta scores are the most accepted, valid and up-todate methods (6).

There are studies showing that the use of CS prevents the development of PTS, which is a long-term complication of acute proximal DVT, as well as there are studies showing that it has no effect on PTS $(7,8)$. In our study, the early $6^{\text {th }}$ month Villalta score results in patients using CS were compared with patients not using CS, and no significant difference was found in terms of preventing the development of PTS.

It has not yet been clarified in the literature whether choosing a higher pressure and high level CS is effective in the development of PTS or in reducing symptoms. Ten Cate-Hoek et al. (9) found no significant difference between different CS pressures and levels in terms of the efficacy, and a regression in symptoms was observed regardless of the pressure and level of CS. Similar results were obtained in studies in which only low-pressure or high-pressure CS was used and the venous filling index was measured $(10,11)$. In our study, we preferred the use of belowknee and medium-pressure CS for each patient in order to increase patient compliance, we did not use higher pressure and high-level stockings.

\section{Study Limitations}

When the results of studies using VAS scoring were examined to investigate the effect of CS use on pain symptoms in patients with DVT, it was found that CS especially used in the early period, had positive effects on reducing pain (12). Similarly, in our study, a statistically significant difference was found between the $6^{\text {th }}$ month VAS scores of the patients who used CS and those who did not. In the evaluation of pain satisfaction, VAS can be preferred as a valuable measurement method in DVT with acute proximal involvement. Although it is an advantage that this scoring system is easy to understand and re-applicable, it is a disadvantage that difficulties ocur due to declining cognitive functions, especially in older age groups.

\section{Conclusion}

Considering the early results of CS in the treatment of patients with proximal lower extremity DVT, no significant effect was found on the development of PTS. However, in daily practice, they can still be used in symptomatic treatment. Studies that evaluate more patients and include long-term results are needed for efficacy analysis.

\section{Ethics}

Ethics Committee Approval: The study was approved by the local ethics committee and all data were evaluated retrospectively before and after treatment.

Informed Consent: The patients were informed about the treatment to be applied to them, and their consent was obtained.

Peer-review: Externally peer reviewed.

\section{Authorship Contributions}

Surgical and Medical Practices: C.K., M.Ş.B., Concept: C.K., M.Ş.B., E.A., Design: C.K., M.Ş.B., E.A., Data Collection or Processing: C.K., M.Ş.B., A.Ö., E.Ş.D.Y., F.B., Analysis or Interpretation: C.K., M.Ş.B., A.Ö., E.Ş.D.Y., F.B., E.A., Literature Search: C.K., M.Ş.B., Writing: C.K., M.Ş.B.

Conflict of Interest: No conflict of interest was declared by the authors.

Financial Disclosure: The authors declared that this study received no financial support.

\section{References}

1. Wendelboe AM, Raskob GE. Global Burden of Thrombosis: Epidemiologic Aspects. Circ Res 2016;118:1340-7.

Table 2. VAS, Villalta and VCSS scores of the patients

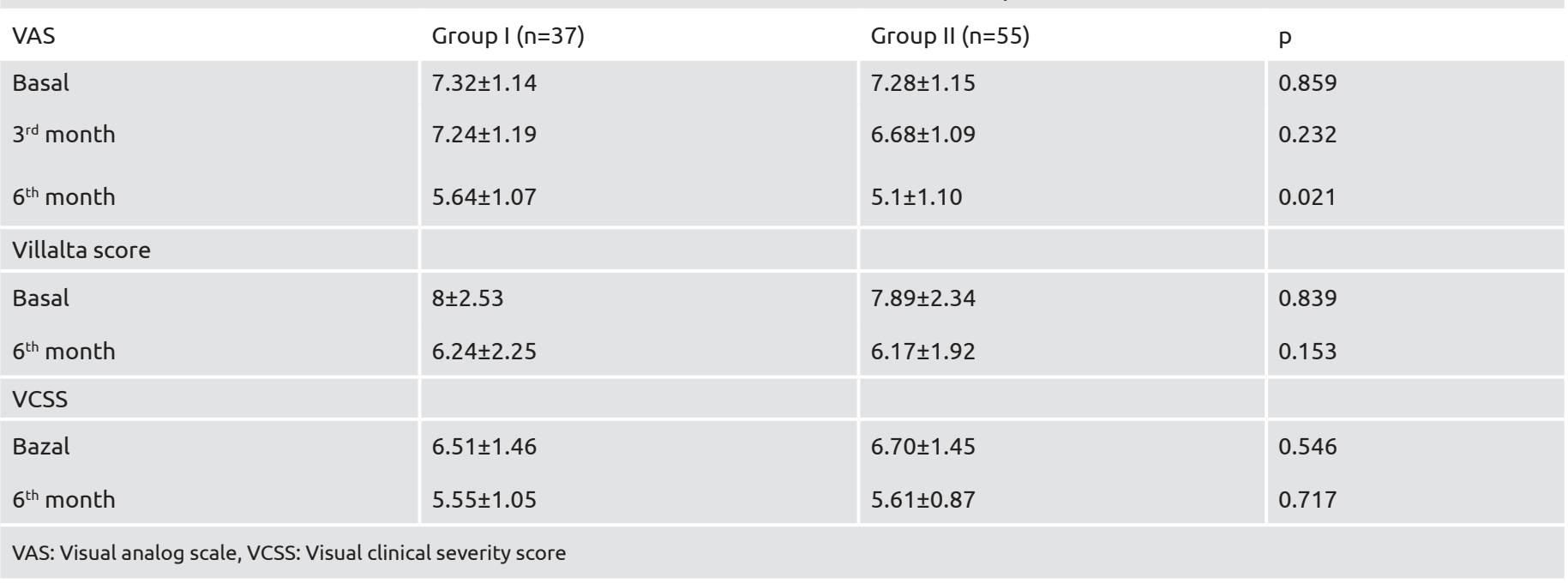


2. Singer AJ, Tassiopoulos A, Kirsner RS. Evaluation and management of lower-extremity ulcers. N Engl J Med 2017;377:1559-67.

3. Tang T, Chen L, Chen J, Mei T, Lu Y. Pharmacomechanical Thrombectomy Versus Catheter-Directed Thrombolysis for Iliofemoral Deep Vein Thrombosis: A Meta-Analysis of Clinical Trials. Clin Appl Thromb Hemost 2019;25:1076029618821190.

4. Avila ML, Montoya M, Lumia C, Marson A, Brandão LR, Tomlinson G. Compression stockings to prevent post-thrombotic syndrome in adults, a Bayesian meta-analysis. Thromb Res 2019;182:20-6.

5. Kearon C, Akl EA, Ornelas J, Blaivas A, Jimenez D, Bounameaux H, et al. Antithrombotic Therapy for VTE Disease: CHEST Guideline and Expert Panel Report. Chest 2016;149:315-52.

6. Rabe E, Partsch H, Hafner J, Lattimer C, Mosti G, Neumann $\mathrm{M}$, et al. Indications for medical compression stockings in venous and lymphatic disorders: An evidence-based consensus statement. Phlebology 2018;33:163-84.

7. Soosainathan A, Moore HM, Gohel MS, Davies AH. Scoring systems for the post-thrombotic syndrome. J Vasc Surg 2013;57:254-61.

8. Mol GC, van de Ree MA, Klok FA, Tegelberg MJ, Sanders FB, Koppen $S$, et al. One versus two years of elastic compression stockings for prevention of post-thrombotic syndrome (OCTAVIA study): randomised controlled trial. BMJ 2016;353: i2691.

9. Ten Cate-Hoek AJ, Amin EE, Bouman AC, Meijer K, Tick LW, Middeldorp S, et al. Individualised versus standard duration of elastic compression therapy for prevention of post-thrombotic syndrome (IDEAL DVT): a multicentre, randomised, single-blind, allocationconcealed, non-inferiority trial. Lancet Haematol 2018;5:25-33.

10. Lattimer CR, Azzam M, Kalodiki E, Makris GC, Geroulakos G. Compression stockings significantly improve hemodynamic performance in post-thrombotic syndrome irrespective of class or length. J Vasc Surg 2013;58:158-65.

11. Zajkowski PJ, Proctor MC, Wakefield TW, Bloom J, Blessing B, Greenfield LJ. Compression stockings and venous function. Arch Surg 2002;137:1064-8.

12. Bademci MS , Kocaaslan C, Aldag M, Oztekin A, Yalvac ESD, Aydin E. Evaluation of early patient satisfaction with visual analogue scale in the treatment of isolated great saphenous vein insufficiency with n-Butyl cyanoacrylate ablation. Medeniyet Med J 2018;33:2127. 